\title{
Conceptual Approaches of Prospective Pedagogy
}

\author{
Lungu Viorelia ${ }^{1}$, Silistraru Nicolae ${ }^{2}$ \\ ${ }^{1}$ Technical University of Moldova, the Republic of Moldova \\ ${ }^{2}$ State University of Tiraspol, the Republic of Moldova
}

\begin{abstract}
.
The theoretical and methodological foundation of Prospective Pedagogy has become one of the key issues of contemporary pedagogy, when exploring various aspects of the science of education related to personality formation, to deal requiments for present and future. The analysis perspectives of the prospective education presented the degree of complexity in terms of the characteristics that were inserted in the research, as conditions of its conceptualization.

Studies of general epistemology state four main conditions that a certain field of knowledge must meet in order to acquire the status of science: to have its own research object, to develop a conceptual and explanatory system; to have its own methods and techniques; investigation of the object of study reunited in a scientific methodology; and, to have a praxiology of the field, in the sense of influencing, directing, and controlling the phenomena it studies. Thus, it confirms the theoretical conceptualization of the paradigm of prospective education, as science of education.
\end{abstract}

Keywords: prospective pedagogy, education foresight, prospectiv.

\section{Introduction}

Restructuring the university education system represents a convenient objective for the development of the Republic of Moldova. The strategic directions of monitoring and development of the university education, described in the policies of sustainable development, have to be elaborated in relation to the worldwide development trends of society.

Although the Education Conception in the Republic of Moldova (2000) claimed a prospective, systemic, formative and dynamic education, centered on general-human and national values, and the prospective aspect remains less upgraded in the educational standards, manuals and curriculum of the university education system etc.

However, as V. Popa [145; 146] sustains in the Report on specific objectives of the education and training system (Brussels, 2001), the representatives of the European Council started from the hypothesis that the society assigns to the education different points of centering, since what particularizes our times is not the existence of change, but its superaccelerated rhythms. Thus, it emphasizes the need to substantiate theoretically and methodologically a new field - Prospective Pedagogy (PP). 
Upgrading the educational process in the light of PP requires a responsible analysis, as the future creates increasingly higher requirements. These requirements need changes depending on PP trends, which will substantiate the elaboration of the new educational policies and the university education system.

Thence, the scientific approach for a possible theoretical and methodological substantiation of the PP became one of the key matters of the modern pedagogy. The need to explore this field in the present is dependent on several factors:

1) the accelerated rhythm of the change, the globalization, the challenges of the $21^{\text {st }}$ century, the innovations and the creativity, the internationalization of the university education;

2) the need to ensure the quality and the performance of human resources at the global, national and local level;

3) the lack of a sustainable policy at the state level in the field of PP ;

4) the shortage of prospective investigations in relation to the education;

5) the weak information level of specialists in the field of education as the report between the demand of labor market, society and the university offer;

6) the skills of the specialist needed on the labor market.

Simultaneously, when different aspects of education science are explored, the Prospective Pedagogy as fundamental field is not researched in details, is not conceptualized. This situation is seen as a dilemma or a shortcoming of the education sciences. The emphasized prospective character in education confirms its importance in training the personality to integrate into society and the labor market.

In this sense, M Stanciu (1999, p. 21) considers that the young people have to be prepared prospectively. The education will have to give to the individual that "interior compass" orienting them better in the future.

The purpose of the research resides in the theoretical and praxeological substantiation of the prospective education paradigm within the university in order to develop and to anticipate the educational process of the Republic of Moldova and to establish the level of planning the prospective skill in the university curriculum to train prospectively and professionally the emerging specialists, directed toward values of sustainable/prospective development of the education institutions/society.

In order to achieve the purpose, several objectives of the research are outlined:

1. Analyzing in multi-aspectual way the epistemological fundamentals of the prospective education under the conditions of the continuous educational reforms in the permanent education.

2. Conceptualizing the Prospective Education as a new paradigm in founding the Prospective Pedagogy (PP);

3. Elaborating and validating by experiment the paradigm of the Prospective Education.

The research methodology meets the object, the purpose and the referred sources and constituted of:

a) theoretical methods: scientific documentation, theoretical synthesis, deduction, generalization and systematization, comparison, transfer of theories;

c) experimental methods: pedagogical experiment including: direct observation, testing, questioning, conversation;

d) statistic methods: data collection, mathematical statistics. 
To realize the multi-aspectual analysis of the prospective education's epistemological fundamentals, the specialty literature was analyzed to identify the place of PP in the system of education sciences.

\section{Prospective pedagogy in the system of education sciences}

Following the analysis of the specialty literature, we observed that the Prospective Pedagogy localized differently in the system of the education sciences based on certain criteria. As argument, we propose a table showing the fact that the Prospective Pedagogy frames as fundamental theoretical field:

Table 1 Framing Prospective Pedagogy in the system of education sciences

\begin{tabular}{|c|c|c|}
\hline rs & on & hg prospective pedagogy \\
\hline sănescu (1978) & of generality & $\begin{array}{l}\text { ciplines forming the trunk of } \\
\text { l pedagogy }\end{array}$ \\
\hline $\begin{array}{l}\text { of Pedagogy Course } \\
\text { ed by the University of } \\
\text { rest }(1998, p .358)\end{array}$ & $\begin{array}{l}\text { ends ascertained in the process of } \\
\text { fying the study field of pedagogy } \\
\text { ing the jump from the pedagogy to the } \\
\text { of education sciences }\end{array}$ & $\begin{array}{l}\text { es studying certain special } \\
\text { s of the education impelled at the } \\
\text { f pedagogical research }\end{array}$ \\
\hline avei (1996, p.76-77) & of generality & nental theoretical field \\
\hline traru $(2002$, p.17) & $\begin{array}{l}\text { ing the research methods/interpretation } \\
\text { cation related matters }\end{array}$ & dological pedagogical sciences \\
\hline $\operatorname{lgu}$ & of generality & hental theoretical field \\
\hline
\end{tabular}

Source: (created by author)

Framing the Prospective Pedagogy in the fundamental field of the System of Education Sciences may be observed also at I. Bontaş, I. Jinga şi E. Istrate, (1998, p.22), but these authors quote also Şt.Bărsănescu. O. Dandara has the same opinion and she framed PP in fundamental sciences approaching it analytically in temporal context in the course „Pedagogy”, appeared in 2010 and describing the classification of education sciences adapted according to E. Macavei (1996, p.19). Therefore, we ascertain that a good part of the authors of the Romanian area do not have research in the prospective field.

We have to remark that the Model of M. Gatson (1981, p. 359) proposes as sciences those referring to the reflexive and prospective analysis of the future: education philosophy, education planning, and at C. Birzea $(1976$, p. 22) we find the education planning at the criterion: predominant research methodology.

PP approached as fundamental field of education sciences permits to conclude that it has as object of study the prospective education - a new paradigm.

There are many interpretations of the "paradigm" notion. In the science philosophy, G. Bergman introduced the term, but Thomas Kuhn contributed essentially to upgrading scientifically the term. The last defines the paradigm as a set of ideas, believes shared by the scientific community, based on prioritized scientific "realization" defining the researched and solved matters - taken from the practice of normal science." (Th. Kuhn, 2008)

As current aspect, sustains Dm. Patrascu, the paradigm circumscribes on what supports the new researches in the science philosophy. Paradigm - 1) it is an initial conceptual schema, the model of stating a matter and its settlement, the research methods, dominated during a historical period; 2) theory (model, type of stating the matter) accepted as example 
in solving the research tasks. We understood by the pedagogical paradigm (from Greek model, ensample, learning) the general picture of education, as model for pedagogical action (Dm. Patrascu, 2005, p. 46).

The most accepted interpretation of the "paradigm" term in our research is that of "model", aspiring to reproduce the essential elements of original, natural or socially studied phenomena and processes.

\section{Theoretical basis for the elaboration and the development of the prospective pedagogy}

The pedagogy is an theoretical-praxiological science, where the knowledge and the action, the explanation and the application, the theory and the practice, are inseparable sides of the perspective, from which it assumes the education as own object. This distinctive note of the pedagogy is emphasized by several authors. In this sense, R. Hubert mentions that the pedagogy is a practical science and thinking; E. Planchard considers that we differentiate the descriptive plan (of the knowledge) and the normative plan (of the action) in the pedagogy; J.S. Bruner, referring to the theory of training, shows that it was not only descriptive and explicative, but also prescriptive and normative, and D. Todoran highlighted that "the education science, the pedagogy tends to discover the laws intervening to develop the educational phenomena in order to control, manage and plan gradually (apud E. Paun, p. 24).

The theoretical basis constitutes of laws, theories, principles, conceptions, ideas from the field of pedagogy, philosophy, psychology, education philosophy, pedagogical anthropology, ethics and education sociology etc. The research relied on ideas, philosophical-anthropological concepts regarding the prospective education: the matters of selecting the science content for the organization of the education objects (B. O. Smith, 2004), the experience philosophy and the pragmatic instrumentalism (J. Dewey, 1992), the social-economic matters of masses (O. Ghibu, 1998), the approaches of the report between education and society (E. Faure, 1974), the theories relating to the decision-making - the model of expectations (Vroom, 1964).

A peculiar role in this sense ascribes to the theories of preparing the human resources for the future (J. Dewey, 1992), (A. Tofler, 1993), (R. Dottrens, 1971), (Dm. Todoran, 1982), the prospective triangle (M. Godet, 2006), the theories of the change (V.-M. Cojocariu, 2003), the theory of perspective (Kahneman and Tversky, 1979), the theory of expectations (V. Vroom), and others.

We took into consideration, in the delimiting of Prospective Pedagogy in the education process, the theory of Romanian scientist $\mathrm{D}$. Todoran describing prospective education (PE) as one of the sectorial dimensions, together with the economic, technological, political, cultural and social one (D.Todoran, 1982). The interdependence of these dimensions becomes an incontestable reality creating a climate of uncertainty and determines the research of global approaches of matters.

Starting from the idea that "Prospective Pedagogy researches the education from the prospective of the future" (L. Antonesei, 2005) and that the prospective education is namely the type targeting explicitly the transformation and the future, we get to the core of the same antinomy shaking the education field: tradition or modernity, adaptation for mention ( $\mathrm{P}$. Apostol, 1977) or innovation for overcoming. 


\subsection{Functions of prospective education}

We deducted as applicability the functions exercised by prospective education: of anticipation, innovative, of adaptation, of planning, of integration in social life, of orientation.

Figure 1. Functions of prospective education

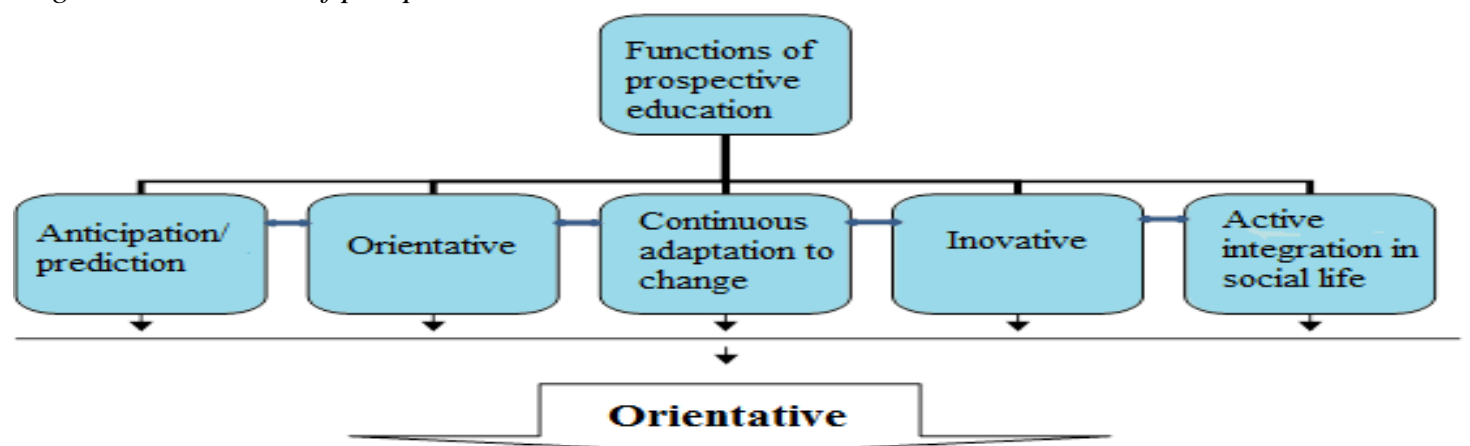

Source: elaborated by author

All these functions have to be seen in unity and interdependence. They represent, in the same time, a report reflecting the specific reality it meets, following its permanent adaptation to the requirements of global social system and to its main perspective subsystems.

The analysis perspectives of PE presented the degree of complexity under the aspect of characteristics that were inserted in the research as conditions of conceptualizing PE. Therefore, the detailed analysis of scientists acceptations in the field of education sciences permitted to establish the specificity of PE: it supposes a holistic, transdisciplinary, probabilistic approach, it has a cognitive structure based on the prediction of an event or phenomenon of education, it represents a type of emerging knowledge, an anticipative, dynamic, participative, operational, euristic and innovative character. (V. Lungu, 2012, p. 40-42).

\subsection{Conditions of Prospective Pedagogy to acquire the status of science}

The study of general epistemology enunciates four main conditions we have to accomplish for a certain field of knowledge to acquire the status of science (Pedagogy Fundamentals):

1) To have its own research object. The Prospective Pedagogy is a field of education sciences plainly justified, which has as its own research object - the prospective education, it being not only a real complex field, but also of maximum importance claiming an appropriate scientific and rational approach.

We identify in the specialty literature (P. Apostol; R. Dottrens) different approaches related to PE. We accepted as starting point in our research the definition of $\mathbf{R}$. Dottrens characterizing PE by the orientation toward the future, having as object of study the probabilities of collective evolution in order to establish the fundamentals of an education adapted to the situations and the requirements of tomorrow (R. Dottrens 1971, p. 93).

P. Apostol (1977) considers that PE refers to a global, peculiar systemic function of social complexes, the one of "production/reproduction", more exactly of forming types of personality appropriate to a society in a determined stage of its history. 
M. Stanciu asserts that PE is a methodical investigation of the future by using an approach favoring the changes and the renewals. In contrast to the futurology, the prospective tries to avoid the rupture between the past and the future (1999, p. 16).

At the core, the PE conceptual analysis supposes the clear delimitation of invoked term's functionality. We consider that PE as the study object of PP, may be interpreted from several perspectives:

- as field of science, addressed to the study of factors, mechanisms of prospective construction, development of prospective and competent personality for the present and the future etc.;

- as dimension of the education system and other systems;

- as continuous process of gathering and forming values, prospective personality;

- as study discipline of the educational process aimed at forming prospective skills;

- as compound/method of integrating and applying in other disciplines;

- as infusional element in the area of different disciplines etc. (V. Lungu, 2012).

2) To elaborate a conceptual and own explicative system, compiled of concepts, judgments and laws (utterances), capable to overcome the descriptive phase and to allow the access to explanation and prediction. PP in the Republic of Moldova is currently at the phase of constituting a conceptual and own explicative system needing the development of exact and stable pedagogical language under the report of meanings. Although the degree of conceptualizing does not achieve the rigor and the precisions of other sciences, the scientific status of concepts and prospective pedagogical utterances cannot be questioned, as it is validated by the formal and non-formal educational practice, and was emphasized some concepts (prospective, prospective character, prospective education, prospective pedagogy etc.) in the specialty literature (G. Berger; S. Cristea; J. Dewey; R. Dottrens; D. Todoran, etc.). The conceptual analysis of proposed terms needs to delimit the notions and the respective contents. We find in the use of more terms in the specialty literature: prospective pedagogy, prospective education etc., each having, as we mentioned, a common spectrum of matters and a specific analysis of the educational field.

This perspective leads toward the analysis of different approaches of PE. Due to these considerations, it relies on three existing concepts: prospective education (D. Todoran, 1982), prospective pedagogy (E. Macavei, 1966) and the prospective character of education (N. Silistraru, 2001). Although the delimitation of these concepts was approached partially, a comparative analysis of them was not realized at theoretical-practical level.

In our opinion, the prospective education is an anticipative activity, being orientated, by outcomes, toward future. We join the opinion of the scientist V. M. Cojocariu (2003), mentioning that under the current society's conditions, accelerated evolution rhythm, it is necessary to impel the training a personality capable to settle matters of life and activity.

As for the term the prospective education, D. Todoran (1982, p. 197) defines it as training the individual for future and in the future. The author sustains also that the prospective education, largely, covers any research and futurist construction, and narrowly, refers to researches and studies on the possible future in this field.

The expression Prospective Pedagogy was introduced in the pedagogical language for the first time by G. Berger, who suggested the idea of a new direction, but he did not develop it. His ideas were taken by the promoters of the permanent education (G. Berger, p. 5). 
The analyzed definitions clarify the difference education them, where the prospective pedagogy aims at orienting the education toward the requirements of the future, and the prospective education represents a systemic study of educational systems models, of future processes and education systems, highlighting the conceptions of future education.

Significant in our research is the prospective character of education imposing a double conditioning: the appropriate reporting to the characteristics of future society and the functioning of present society. Due to its prospective character, the education not only adapts to the specificity of anticipated changes, but also prepares the conditions resulting in these changes and it models by current actions the specificity itself of the future society. S. Cristea (2015, p. 16) reveals that one of internal characteristics of education policy is the prospective character emphasizing that the education activity always aims at a future, strategic, current and conjectural situation.

The absence of the professional and scientific terminology of the "prospective" category, which would meet the correlative notion of "perspective", "proactive", leads to the terminological shortage.

We want to specify that the need to substantiate the new notions in the pedagogical science is due to several factors:

1. the significant increase of the importance of prospective character of the prospective education and dimension in training and evaluating the processes of social and personal development along the way;

2. the need to institute within the education sciences the field that would substantiate the correlation of educational actions from the past - present - future, reported to the present and future needs of the individual personality and the entire society. The educational system has to provide to the beneficiaries possibilities to develop the skills with prospective accent;

3. the non-conformity of traditional pedagogical notions used previously ("the perspective education", "the prospect of future, "the planning of education", "the education through change and development", "the education for tomorrow" and other variations), which do not reflect the essence of the object, on the contrary, it limits its comprehension, that's why the local culture comes with multiple and controversial connotations of "prospective" term.

In essence, at level of concept, PE was reported to the current and perspective requirements of the society by orienting toward a new modality of education providing to the individual the possibility to face the unpredicted events, by anticipation and participation. Therefore, PE may be analyzed: largely and narrowly.

- Largely, PE provides a new value organization of the personality's expectations through value and significant hierarchy of skills contributing to the achievement of the educational ideal.

- Narrowly, PE represents an organized and designed process of personality's development for future from biological, psychological and social point of view, of training the consciousness and the proactive behavior of the active integration in the social life, which changes continuously (V. Lungu, p. 18).

For the development of the conceptual framework mentioned above, we propose the introduction of prospective skill as necessary functional category in the following formula: the prospective skill represents a finalized structure, generated by the mobilization of 
subject's internal resources quantum in a delimited framework of significant situations (pedagogically deliberate or spontaneous, with disciplinary or inter-disciplinary character) and manifesting by anticipation, planning and sense assignments and action's direction (V. Lungu, p.58).

2) To have own investigation methods and techniques of the study object, reunited in a scientific methodology able to provide and to produce true, verifiable and pertinent information about the reality studied by science. PP has own methods and techniques of researching the study object, reunited in a pertinent scientific methodology. Although many of methods are taken from other sciences, especially from psychology and sociology, economy, these methods are integrated in a unitary pedagogical methodology, adapted to the objectives, requirements and peculiarities of researching the educational phenomenon by the prospective dimension and character.

In fact, the prospective pedagogical research contributes to the development of methods, to the validation of new research techniques, realizing transfers with other sciences participating in the interdisciplinary research of PE.

Many theories directly bear the print of prospective methods: prospective analysis, Delfi method, future's alternative modelling and others. Together with empirical and theoretical methods of studying the future (D. Todoran, p. 205) are emphasized the methods of designing and modeling the future, methods of learning and methods of assesment.

A varied series of prediction methods may be used in the prospective methodology, which are used in the training-educative process. Project development method may be useful in more stages of the decision-making process. The scenario may serve as approximate prediction technique of a "fascicle" in the stage of information, of possible evolution of matter or trend. As heuristic education methods, we use in our research the problematization, the method of projects etc.

4) To have a praxeology of the field, i.e., principles, norms and rules of practical actions, methods, tools in the sense of influencing, directing and controlling the phenomena it studies. PP has a praxeology of the field, norms and principles of practical action. It is, without doubt, the condition and, meanwhile, the peculiarity of PP. Before becoming a scientific theory, PP was approached in the practice: in the field of planning, business, environment, economy and policy studies (E. Stan, 2004), in developing the technology or anticipating the evolution directions at the level of human resources, applying principles and methods verified experimentally, partially conceptualized by the philosophy, pedagogy, sociology etc. In this sense, PP is the theoretical conceptualization of PE experience.

$\mathrm{PP}$ relies on the fundamental principles related to the educational process by considering the prospective specificity. In this sense, we consider that the functionality of PE Paradigm may be ensured by respecting the following specific principles: principle of social stringency and global approach, principle of temporal perspective, principle of social stringency, social and individual axiological principle, principle of learning by experience and principle of anticipating, orienting and designing prospectively the education. (V.Lungu, p. 74-75). It is important to complete these principles with the principle of golabalism and the constructivist principle 
The formulated principles serve as theoretical and normative foundations in order to achieve the expected effect to meet the PP objectives and represent the nucleus of elaborated model.

Following the respect of PP principles in the education institutions, PE will make its presence felt, therefore being realized the desiderata of the education process to be rethought the present from the perspective of the future and implicitly, being provided the quality and the performance of the human capital.

Together with other pedagogical sciences, PP may be considered as a science with theoretical, gnoseological character, answering to the question what is PE and, elaborating the prospective pedagogical theory, it contributes to the development of human knowledge, generally. PP is a science and has a praxiological character in order to answer to the question what is PE and therefore, relying on the laws of education and on the pedagogical theory with the strategies and the technologies (methods, forms, means) of training and educating the new generation, manifests hence as a science with an efficient educative action.

$\mathrm{PP}$ is a dynamic science, open to changes and innovations, planning prospectively the appropriate strategies for the future.

In the context of the abovementioned facts, we propose the complex definition of the prospective pedagogy: Prospective Pedagogy (PP) represents a fundamental field of the education sciences, which based on the general and specifically prospective education strategies and laws, studies and substantiates appropriately the process of training the prospective personality.

Largely, PP represents a fundamental field of education sciences with theoretical, praxiological and prospective character, which studies and manages the value adaptation and change process and has the outcome to train an integrally developed and prospective personality, capable to face the social transformations, substantiating plainly the potential and the skills, contributing to the achievement of the educational ideal.

Narrowly, PP studies the organized and planned educative process of the personality's development for the future, of training a consciousness and proactive behavior of active integration in the social life in continuous change.

The value validation of exposed ideas led toward new theoretical-applicative considerations, which ascertain theoretical and methodological fundamentals of PE. They will be pertinent as distinctive field of PP if it constitutes as educational paradigm with theoretical-applicative character by:

- valorization of anticipation and planning as fundamental elements of EP;

- determination and structure of prospective values in the context of fundamental human values;

- approaching the education institution from the prospective aspect;

- elaboration of structural compounds of PE paradigm:

- PE pedagogical model in formal - non-formal - informal plan,

- PE transdisciplinary model in the context of new education;

- PE technological model.

In this regard, we may assert that PE paradigm represents the series of interconnected models, centered on training the prospective skill of specialists, organized based on the general principles of learning and prospective approach of education, psychological- 
physiological and social characteristics of the individual, having as outcome the training of the prospective personality, expressed by anticipation, planning and direction toward future. The essence of PE Paradigm is shown in Figure 2.

Figure 2. Prospective Education Paradigm

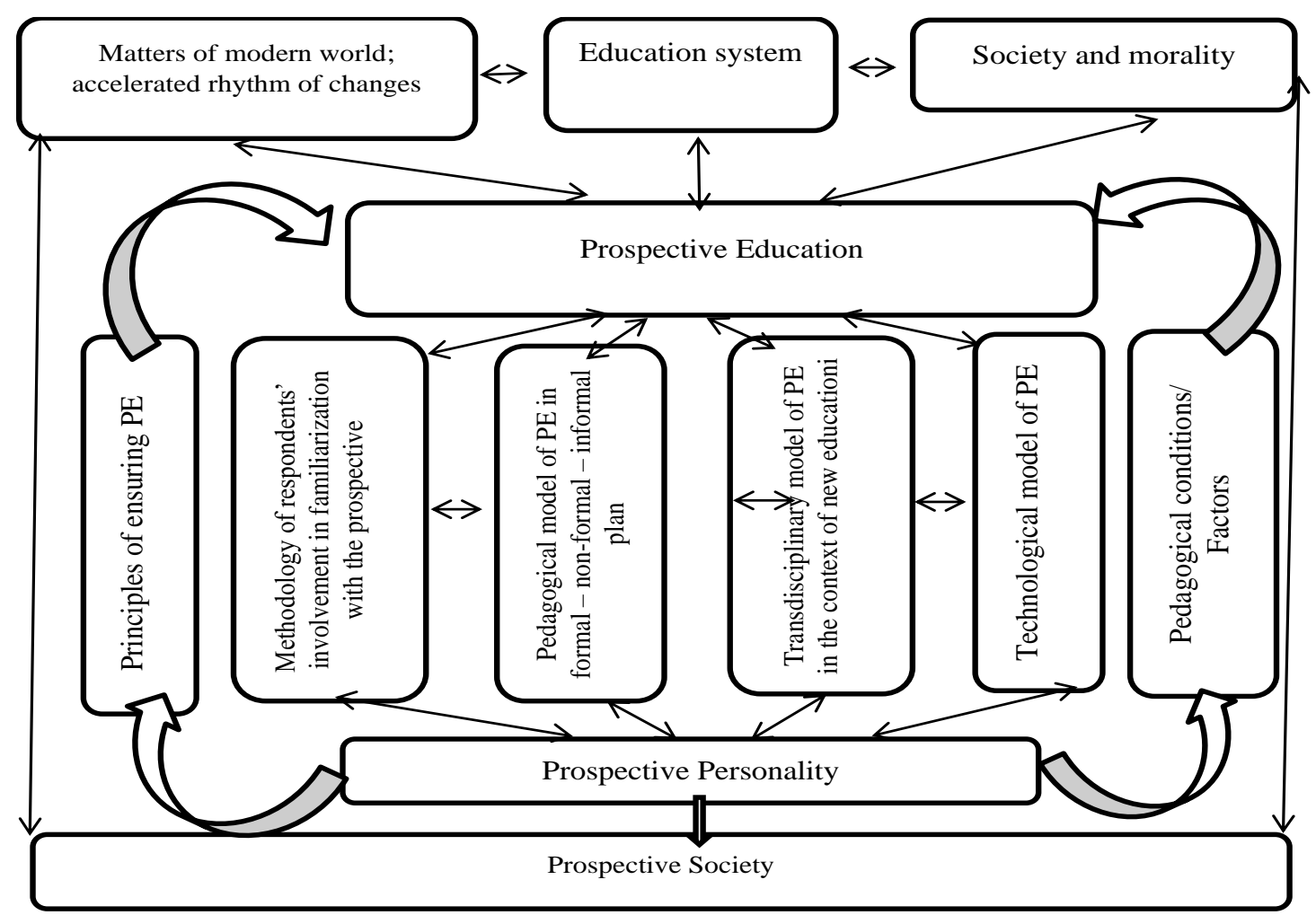

Source: elaborated by the author

The elaborated PE model was validated experimentally in 2 university education institutions of the Republic of Moldova.

The process of training the prospective skills was ensured at two levels:

- through the special discipline "Prospective Education" (30 hours) for pedagogues (cycle I).

- integrated (planning the prospective skill in the curriculum of the discipline Professional Ethics) for students in Engineering and Information Technologies (cycle I). 
Fig. 3. Level of training the prospective skills at the discipline Professional Ethics (pretest/postest)

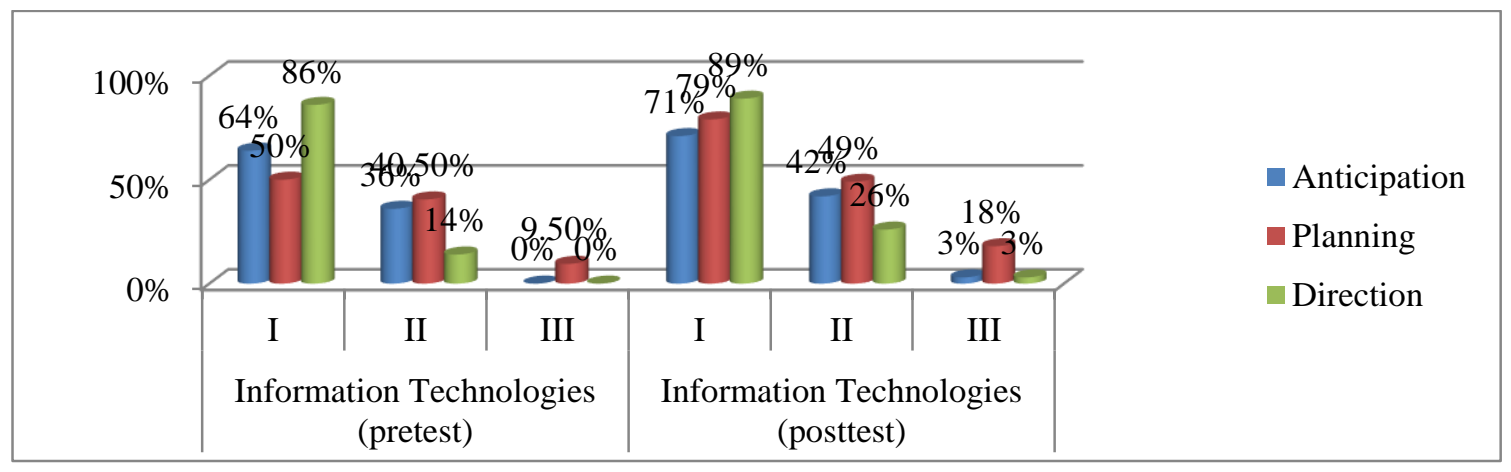

Source: elaborated by author

According to the experimental data, there were modifications at discipline Professional Ethics at different levels of training prospective skills. Therefore: level I of training the anticipation skill increased from $64 \%$ up to $71 \%$ for the IT specialty. Level II of training the anticipation skill increased from $36 \%$ up to $42 \%$. Level III of training the anticipation skill increased from $0 \%$ up to to $13 \%$

Figure 4. Level of trening the prospective skills at the discipline Prospective Education

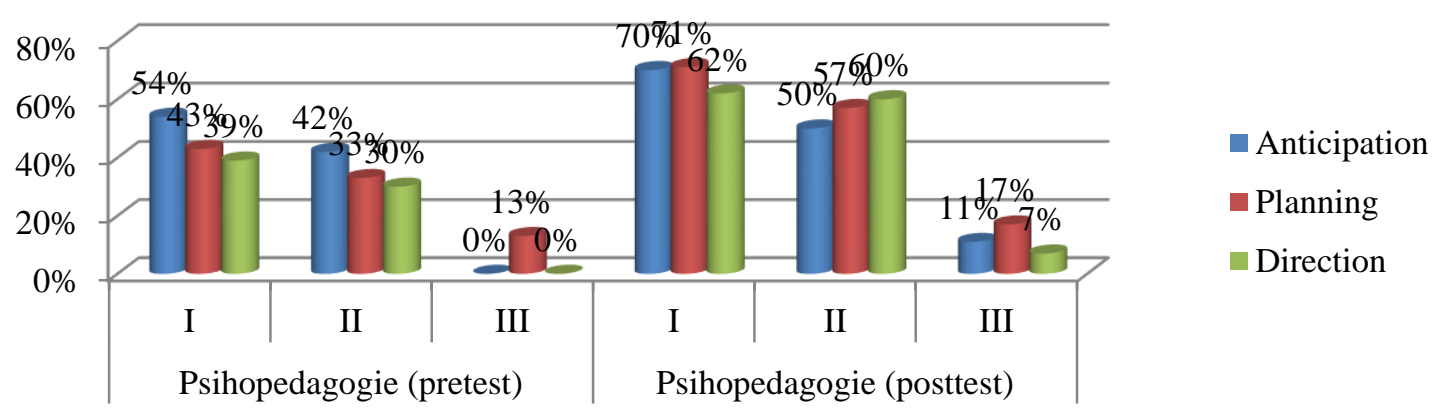

Source: elaborated by author

We observe a different skill training level when analyzing the experimental data as for the level of training the prospective skills at the discipline PE. Hence, at the level I, the anticipation skill increased from 54\% up to $70 \%$ (specialty Psychopedagogy). Level II - the anticipation skill increased from $40 \%$ up to $49 \%$, and the level III - it increased from $0 \%$ up to $11 \%$. The same results were obtained by the infusion implementation of prospective skills in the discipline of Professional Ethics and Basics of Communication.

In closing, we may mention the following:

- the created psychopedagogical conditions (implementation of PE model) contributed to the increase of the prospective skill training level at the level I and II to the stage of ascertainment, at level II and III at the stage of training;

- $\quad$ Training the prospective skills at the level III was registered in approximatively $20 \%$ of training experimental subjects. 
Constituting an important field of education sciences, PP elaborated/adjusted and continues to elaborate its specific categories, which compiles the fundamental language in educational knowledge and action. The PP categories are different dimensions, aspect, elements and their reports as: the prospective education; the prospective training; ideal, objectives and prospective educational principles; PE curriculum; methods and forms of didactic activity etc.

Hence, PP is more than a paradigm or a pedagogical norm, it supposes the interference of a specific social system, which includes all learning experiences provided by the society of individual.

The pedagogical experiment showed that the substantiation of PP as a field does not have to exist only as a scientific-theoretical construction for the development of education sciences, but, incontestably, it has to include a series of practical references ensuring its functionality. The basic condition - the knowledge of scientific fundamentals of PP and the familiarization of university educational beneficiaries with its content.

\section{Conclusions}

In our opinion, the theoretical and methodological substantiation of PE supposes the awareness that it matters for all fields of professional training. The situation requires the needs to integrate PP in the university education system.

1. Analyzing the opinion of scientists in the field shows that PP is a science in a fundamental field or generally, of education sciences. The PP substantiation as an important field of education sciences relied on the main conditions that have to be met by a certain field of knowledge to acquire the status of science.

2. The theoretical and methodological PE Paradigm has the following structural compounds: the PE pedagogical model within formal - non-formal - informal framework, PE transdisciplinary model in the context of new educations; PE technological model is a significant contribution to the development of PP.

3. To train a prospective personality is necessary to review the content of the curriculum in order to introduce the prospective dimension in the initial and continuous professional training of specialists from different fields.

In this context, in case of deep changes of our times related to the introduction and the use of new methods, prospective principles and technologies, accompanied by new organization forms of the education process, the prospective development of a personality becomes a valuable and strategic factor for each educational institution, respectively for the labor market.

\section{Acknowledgment}

This paper is an output of the science project „Postdoctoral Programs” for the years 20212022, priority: Society challenges entitled: Conceptual and Methodological Fundamentals of Prospective Education. 


\section{References}

Antonesei, L. (2005). Polis şi Paideia. Şapte studii despre educaţie, culturi şi politici educative. Iaşi: Polirom.

Apostol, P. (1977). Viitorul. Bucureşti: Ed. Enciclopedică.

Bărsănescu, Ş. (1978). Educaţia, învăţământul, gândirea pedagogică din România. Bucureşti: Editura Ştiinţifică şi Enciclopedică,

Berger, G. (1973). Omul modern şi educaţia sa. Psihologie şi educaţie. Bucureşti: Ed. Didactică şi Pedagogică.

Bîrzea, C. (1976). Reforme de învăţămînt contemporan. Tendinţe şi semnificaţii. Bucureşti: Ed. Didactică şi Pedagogică.

Cojocariu, V.-M., (2003). Educaţie pentru schimbare şi creativitate. Bucureşti: Ed. Didactică şi Pedagogică, $312 \mathrm{p}$.

Cristea, S. (2015). Dicţionar enciclopedic de pedagogie. Volumul I (A-C). București: Didactica Publishing House.

Dewey, J. (1992). Fundamente pentru o ştiinţă a educaţiei. Bucureşti: Ed. Didactică şi Pedagogică.

Dottrens, R. (1971). Institutori ieri. Educatori mîine. Bucureşti: Ed. Didactică şi Pedagogică.

Dandara, O. (2010). Competenţa gnoseologico-conceptuală. În: Pedagogie: Suport de curs. Chişinău. pp.17- 29.

Faure, E (1974). A învăţa să fii. București: Ed. Didactică şi Pedagogică,

Fundamentele pedagogogiei https://www.scribd.com/doc/46424209/Capitolul-1

Gaston, M. (1981). Introducere în pedagogie. Bucureşti: Ed. Didactică şi Pedagogică,

Gibu, O. (1998). Pedagogia Militans. Bucureşti: Ed.Semne.

Gidley, J., Batemen D. and Smith C., (2004). Futures în Educaţion. Principles, practice and potential. Monograph series, Australian Foresight Institute.

Godet M. (2006). Creating future. Scenario Planning as a Strategic Management Tool. France: Economica.

Jinga, I. and Istrate, E. (1998). Manual de pedagogie. Bucureşti: ALL.

Kahneman, D. and Tversky, A. (1979). Prospect Theory. An Analysis of Decision Under Risk. În Econometrica, XLVII, N.2. $\quad$ Vol.47, pp.263-291. https://www.uzh.ch/cmsssl/suz/dam/jcr:00000000-64a0-5b1c-0000-00003b7 ec704/10.05kahneman -tversky-79.pdf

Kuhn, Th. (2008). Structura Revolutiilor Stiintifice. Bucuresti: Editura: Humanitas.

Lungu, V. (2012). Conceptualizarea educaţiei prospective în cadrul universitar: Teza de doctor în Pedagogie. Chişinău.

Modelul de Curs de pedagogie (1988). Universitatea Bucureşti .

Macavei, E. (1996). Pedagogie propedeutică. Didactică. Bucureşti: Editura Didactică şi Pedagogică,

Patrașcu, Dm. (2005). Tehnologii educaționale. Chișinău.

Păun, E. (1982). Sociopedagogie şcolară. Bucureşti: Ed.Didactică şi Pedagogică.

Silistraru, N. (2002). Note de curs la Pedagogie. Ediţia a II-a, revăzută şi adăugată. Chişinău.

Silistraru, N. (2001). Dinamica şi funcţionalitatea dimensiunilor educaţiei. Chişinău: I.Ş.E.

Stan, E. (2004). Pedagogie postmodernă. Institutul European.

Stanciu, M. (1999). Reforma conţinuturilor învăţământului. Cadru metodologic. Iaşi: Polirom. 
Todoran, D. (1982). Prospectiva educaţiei şi învăţământului. În: Problemele fundamentale ale pedagogiei. Bucureşti: Ed. Didactică şi Pedagogică, p.197-213.

Tofler, A. (1993). Socul viitorului. Bucureşti: Ed.Politică.

Vroom, V. (1964), Work and Motivation. New York: John Wiley. 